
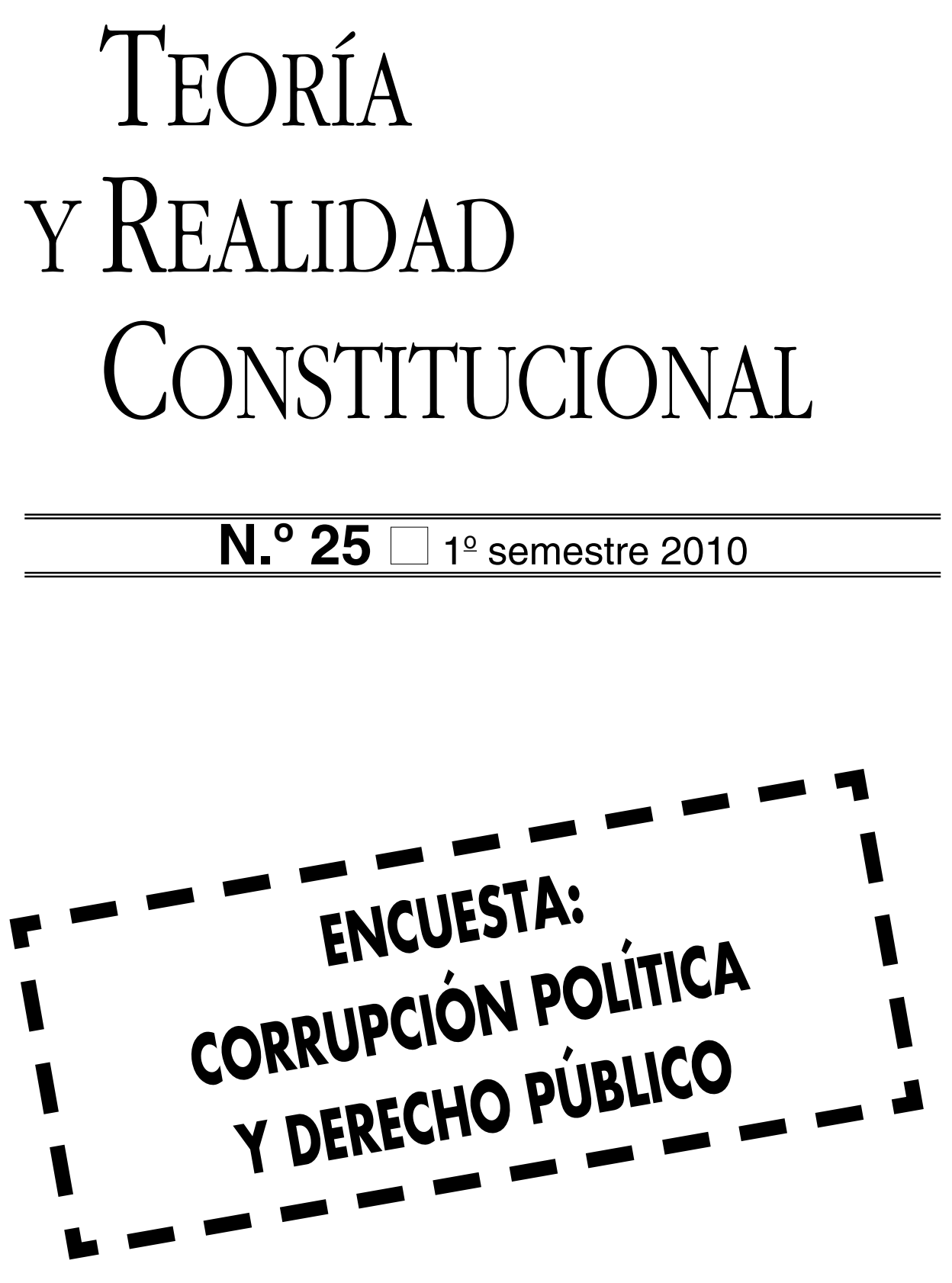


\title{
ALGUNAS CUESTIONES SOBRE EL DERECHO A LA TUTELA JUDICIAL EFECTIVA DE LOS EXTRANJEROS A LA LUZ DE LA JURISPRUDENCIA CONSTITUCIONAL Y DE LA LEY ORGÁNICA 2/2009
}

\author{
JESÚS M. ${ }^{a}$ GONZÁLEZ GARCÍA ${ }^{1}$ \\ Profesor Titular de Derecho Procesal \\ Universidad Complutense de Madrid
}

\section{SUMARIO}

I. Planteamiento.

II. El derecho a la tutela judicial efectiva como derecho de los extranjeros: tratamiento diferenciado de los extranjeros y de los españoles en materia de tutela judicial.

III. Algunos casos de tratamiento diferenciado a los extranjeros y a los españoles, desde el punto de vista de la tutela judicial efectiva.

IV. Tutela judicial efectiva y asistencia letrada en los procedimientos de la ley de extranjería.

V. La Tutela judicial del extranjero como garantía de respeto contra la actuación de los poderes públicos y medidas restrictivas de derechos en procedimientos administrativos derivados de la legislación de extranjería. 


\section{PLANTEAMIENTO}

1. La reciente publicación (cuando estas líneas se escriben) de la Ley Orgánica 2/2009, de 11 de diciembre, de reforma de la Ley Orgánica 4/2000, de 11 de enero, sobre derechos y libertades de los extranjeros en España y su integración social —en adelante, Ley de Extranjería o LO 2/2009- supone la culminación momentánea de un extendido debate jurídico, abierto en los últimos años, sobre el alcance de los derechos de los extranjeros en España así como sobre sus límites, su contenido y sus cauces de ejercicio. En ese debate, y - por qué no decirlo también- en el resultado final del proceso de reforma legislativa, ha jugado un papel decisivo el Tribunal Constitucional, el cual ha ejercido una vez más su doble función de legislador negativo pero también de intérprete positivo de la ley, marcando el paso, si se me es permitida la expresión, de las Cortes Generales a la hora de regular el estatuto jurídico de los extranjeros en España, a través de una serie de resoluciones en las que ha ido definiendo, de forma paulatina, la doctrina constitucional sobre los derechos de los extranjeros en España, y, a su través, estableciendo las fronteras del legislador positivo en la materia.

Dentro de la variedad de matices jurídicos y constitucionales asociados a la extranjería, acrecentados desde un punto de vista social por el crecimiento del fenómeno de la inmigración y el cambio de rol de España en el concierto internacional, el presente estudio se centra en uno de los aspectos que presenta mayores aristas, cual es el de la tutela judicial de los extranjeros, conforme la nueva norma y a la luz de la doctrina constitucional. Huelga decir que el aumento de las tasas de inmigración en España tiene incidencia directa en la Administración de Justicia, no sólo por el mero hecho de que la incorporación de cualquier ciudadano o grupo de ciudadanos a una nueva comunidad determina la constitución de negocios en el ámbito privado y el establecimiento de vínculos jurídico-públicos entre los nuevos ciudadanos y las Administraciones públicas, en definitiva, un nuevo contexto determinado por los nuevos sujetos que actúan en el tráfico jurídico y que, en caso de controversia, necesitan de la jurisdicción para poner remedio, por cauces pacíficos, a sus litigios.

Por este motivo, el incremento del número de extranjeros que viven o que pretenden vivir en España trae como consecuencia el crecimiento de las probabilidades de que los tribunales de justicia aumenten sus tasas de litigiosidad; ello sin tomar en consideración la incidencia que la inmigración masiva de extranjeros, con todas las dificultades que ello genera en su proceso de integración en una sociedad abierta pero ya establecida, puede implicar en el terreno de la conflictividad social y en la aparición de nuevas modalidades de delincuencia, con directa afectación, de nuevo (y a causa de la garantía jurisdiccional en la aplicación del ius puniendi) de la jurisdicción ordinaria.

La incidencia del fenómeno de la inmigración masiva hacia España se ha hecho sentir en la estadística judicial. El Estudio sobre la Planta Judicial ${ }^{2}$ ela-

2 Disponible en la web del Consejo General del Poder Judicial, www.poderjudicial.es. 
borado por el Servicio de Inspección del Consejo General del Poder Judicial (y que se basa en la carga de trabajo que soportan los órganos judiciales en virtud del volumen de entrada de asuntos en el tercer trimestre de 2008), proponía el incremento del número de Juzgados de lo Contencioso-Administrativo de 23 a 94 en toda España, en atención a la sobrecarga que los asuntos de extranjería provocaba en este orden jurisdiccional. En efecto, de 2004 a 2008 la población extranjera empadronada pasó de poco más de tres millones a cinco millones doscientas mil personas, con un incremento del volumen de asuntos ingresados en los juzgados de lo contencioso-administrativo relacionados con la extranjería, en ese mismo periodo, de más del ochenta y seis por ciento $^{3}$, a los que hay que sumar el ochenta y cinco por ciento de incremento de asuntos ingresados ante Juzgados de Instrucción relacionados con esta misma materia ${ }^{4}$. En los datos de la Memoria del Consejo General del Poder Judicial correspondiente al año 20085, el incremento de asuntos ingresados en materia de extranjería en los juzgados de lo contencioso-administrativo se elevaba, a 1 de enero de 2009, a 57.910, casi un treinta y tres por ciento más que el 1 de enero de $2008^{6}$ : el fenómeno de la extranjería incide, pues, en la actividad jurisdiccional, afectando a la capacidad resolutiva de sus órganos y, colateralmente, al resto de procedimientos pendientes ante ellos ${ }^{7}$.

Sin embargo, la problemática derivada del crecimiento de la población extranjera en España no se reduce a las dificultades organizativas de la jurisdicción ordinaria para dar respuesta con eficacia y prontitud a los litigios que nacen en relación con los derechos y deberes de los extranjeros. Junto a este asunto, interesante desde el punto de vista de la organización judicial y de la capacidad de respuesta del Estado ante un fenómeno emergente y con alto volumen de litigiosidad, se plantea otro de no menor interés: nos referimos a algo más nuclear, cual es el hecho de la aptitud de los extranjeros para ser titulares de los derechos y deberes inherentes al proceso, y para ejercitarlos válidamente ante los tribunales, en condiciones de igualdad con los nacionales españoles.

3 De 30.762 en 2004 a 57.507 en 2008, según la encuesta La Justicia dato a dato, Madrid, Consejo General del Poder Judicial, p. 62.

4 De 13.131 en 2004 a 24.387 en 2008, según La Justicia dato a dato, cit., págs. 62 y 63.

5 Aprobada plenariamente el 26 de mayo de 2009 y presentada por el Presidente del CGPJ ante la Comisión de Justicia del Congreso de los Diputados el 14 de diciembre de este mismo año.

6 Este crecimiento alcanzó en Madrid la cifra del sesenta y seis por ciento, y en Murcia, del cuarenta y dos y medio por ciento, según los propios datos de la Memoria del CGPJ correspondiente a 2008.

7 Para conocer mejor la visión de este asunto desde el punto de vista de la Justicia, nos remitimos al Discurso pronunciado por Francisco José Hernando Santiago, como Presidente del Tribunal Supremo y del Consejo General del Poder Judicial, ante S. M. el Rey, en el Acto de Apertura del Año Judicial, el 16 de septiembre de 2002, con el título "Extranjeros, pero no extraños, ante la Justicia", publicado junto con la Crónica de Jurisprudencia del Tribunal Supremo el año 2002. 
En las siguientes páginas se analiza la evolución de la jurisprudencia constitucional sobre el asunto ${ }^{8}$, sin perder la atención de la nueva regulación operada en virtud de la LO 2/2009. Para ello, se pone la atención en determinadas actuaciones procesales en donde se brindaba un tratamiento diferenciado a los españoles y a los extranjeros. Por último, se abordan dos puntos de especial interés, desde el plano constitucional-procesal: por un lado, algunos problemas que la asistencia letrada plantea en los procesos en que alguna de las partes es de nacionalidad extranjera y, por otro, el juego de la jurisdicción con garante del respeto de los derechos fundamentales de los extranjeros, en especial en caso de actuaciones coactivas de los poderes públicos contra ellos.

\section{EL DERECHO A LA TUTELA JUDICIAL EFECTIVA COMO DERECHO DE LOS EXTRANJEROS: TRATAMIENTO DIFERENCIADO DE LOS EXTRANJEROS Y DE LOS ESPAÑOLES EN MATERIA DE TUTELA JUDICIAL}

Comenzaremos, de este modo, por hacer una primera reflexión referente a la titularidad del derecho fundamental a la tutela judicial efectiva del Art. 24.1 de la Constitución. Se trata, a nuestro entender, de una premisa sine qua non antes de abordar otras cuestiones de relevancia referentes al objeto de este estudio, toda vez que el debate sobre el derecho a la tutela judicial de los extranjeros debe partir, desde un punto de vista argumentativo, del reconocimiento a los extranjeros de la titularidad del derecho a la tutela judicial. Sólo desde esa aceptación previa tiene sentido el análisis posterior de cómo se materializa el derecho a la tutela judicial de los extranjeros.

A priori, la cuestión no debería plantear problemas de interpretación. El Art. 24.1 de la CE atribuye el derecho a la tutela judicial efectiva a "todas las personas". Por su parte, el Art. 24.2 de la CE, al enumerar el elenco de garantías y derechos procesales que gozan de la protección expresa de la Constitución, se refiere a "todos" ". En el plano de la legalidad ordinaria, el Art. 20.1 de la LO 4/2000, (LODLE), no reformado por la LO 2/2009, reconoce a los extranjeros el "derecho a la tutela judicial efectiva".

La extensión del derecho a la tutela judicial a "todos", independientemente de su nacionalidad o de su ciudadanía, tiene sentido en atención al carácter absoluto que se debe reconocer a la tutela judicial, como garantía de la

8 Sobre la más reciente jurisprudencia constitucional, recomendamos la lectura de RUIZ DE HUIDOBRO DE CARLOS, J. M., MARTÍNEZ GARCÍA, C., "Las decisiones administrativas en frontera sobre admisión de extranjeros: cuestiones de fondo y garantías jurídicas. análisis de jurisprudencia reciente", Diario de jurisprudencia El Derecho, n. ${ }^{\circ} 2404$, págs. 1 y ss..

9 Coincidimos en este punto con la mayoría de los autores, representados aquí por ESQUEMBRE VALDÉS, M., "Comentario al Art. 20", Comentarios a la Ley de Extranjería (dir. J. Asensi Sabater), Edijus, 2001, págs. 185 y 186. 
efectividad de otros derechos. En un estado de derecho, en el que se atribuye a la jurisdicción la exclusividad en la tutela de los derechos y libertades, no parece tener sentido negar la posibilidad de recabar la tutela de los tribunales a aquellos a quienes se les reconocer capacidad jurídica, esto es, capacidad para ser titulares de derechos y obligaciones, o de ser sujetos pasivos de la actividad jurídica del Estado ${ }^{10}$. Ello supondría una auténtica denegación de justicia, a través de la frustración de las expectativas que los ciudadanos albergan sobre la actuación de la Administración de Justicia cuando no es posible obtener la restauración de la paz jurídica por sus propios medios.

Esta reflexión, que parece elemental $-\mathrm{y}$ que, entendemos, no requiere grandes explicaciones adicionales - sustenta la interpretación que el TEDH hace del Art. 13.1 del CEDH, que reconoce el derecho al recurso efectivo, para la tutela de los derechos y libertades fundamentales. Del repaso de las resoluciones emanadas de Tribunal de Estrasburgo sobre este particular, resulta una variada casuística de supuestos cuyo denominador común lo encontramos en la imposibilidad del reclamante de encontrar una autoridad ante la cual recabar la tutela de su derecho. Al final, la jurisprudencia del Tribunal de Estrasburgo viene a reconocer que es precisamente la posibilidad de actuar los derechos ante los tribunales de justicia la acreditación de la existencia del derecho mismo, como entidad real y no como institución virtual o platónica ${ }^{11}$. Esta opinión es extensible a cualquier ámbito del derecho, pues la coercibilidad es un rasgo inmanente a lo jurídico, aunque - como con frecuencia ocurre en nuestro campo- admita algunas excepciones ${ }^{12}$.

10 Sobre la vinculación entre la personalidad jurídica y la capacidad para ser parte, o aptitud para ser titular de los derechos y deberes inherentes al proceso, y su vinculación con la exclusividad de la jurisdicción y con la prohibición de indefensión vid., dentro de los autores españoles y con mayor extensión, DE LA OLIVA SANTOS, A., Derecho Procesal Civil. El proceso de declaración (con Díez-Picazo y Vegas Torres), Madrid, Ceura, $3^{\text {a }}$ ed., 2004, págs. 135 y ss.

11 Se pueden consultar, a título de ejemplo, algunas del STEDH citadas en nuestro trabajo "La protección de los derechos fundamentales en la Constitución Europea: a propósito del derecho a un recurso efectivo, del artículo 13 del Convenio Europeo para la Protección de los Derechos Fundamentales y las Libertades Públicas", Garantias fundamentales del Proceso Penal en el Espacio Judicial Europeo (Coords. Andrés de la Oliva Santos, Teresa Armenta Deu y Ma Pía Calderón Cuadrado), Colex, Madrid, 2007, págs. 255-272.

12 Estamos pensando, por ejemplo, en el caso de la prescripción de las acciones civiles, en que el demandado tiene el poder, una vez transcurrido el plazo de prescripción, de enervar la estimación de la demanda: ello no significa que el derecho material no exista, o que se extinga, jurídicamente hablando, por el hecho de la prescripción, pues las obligaciones derivadas del derecho prescrito subsisten para el deudor aunque no sean judicialmente exigibles, de suerte que: a) si hubiera cumplimiento voluntario, éste sería válido; y b) se no se opusiera la excepción de prescripción, el tribunal debería estimar la demanda (es, en resumidas cuentas, la noción de obligaciones naturales Sobre la prescripción extintiva y su régimen jurídico, vid. PUIG BRUTAU, J., Caducidad, prescripción extintiva y usurpación, Barcelona, Bosch, 1996; ALBALADEJO GARCÍA, M., La prescripción extintiva, Madrid, Colegio de Registradores de la Propiedad, Mercantiles y Bienes Muebles de España, 2004, DÍEZ-PICAZO PONCE DE LEÓN, L., La prescripción extintiva, en el Código civil y en la jurisprudencia del Tribunas Supremo, Cizur Menor, Civitas, 2007, o YZQUIERDO TOLSADA, M., Las tensiones entre usucapión y prescripción extintiva, Madrid, Dykinson, 1998, entre otros. 
Lo que se acaba de decir sirve para explicar por qué se atribuye a la Administración de Justicia la condición de clave de bóveda del estado de derecho: por una parte, porque a la Jurisdicción le corresponde, a través de la resolución de controversias y desde la actuación de órganos públicos, la definición del derecho, desde la restauración de la paz jurídica, y su efectividad, si es preciso por vía coactiva; por otra, porque a la Jurisdicción se le encomienda igualmente el control en la actuación de los poderes públicos: en este sentido, la Jurisdicción es una garantía de legalidad frente a la actuación de la Administración pública (Art. 106 de la CE). La Administración de Justicia interviene en un estadio temporal posterior (y sobre los materiales que le proporciona) el legislador, y somete a control la potestad reglamentaria y la actuación administrativa: es la garantía última de la efectividad del derecho (y de los derechos). Es en este sentido, colocándonos en la mente del constituyente, como se justifica la extensión del derecho a la tutela efectiva del Art. 24.1 de la CE (con su amplísima caracterización por parte de la doctrina constitucional) a los extranjeros. Pues carecería de sentido, en un estado de derecho, reconocer a los extranjeros capacidad para ser titulares de derechos y obligaciones sin otorgarles, a la par, la aptitud para poder hacer valer esos derechos válidamente ante los tribunales de justicia en España.

Esta última afirmación es válida para el caso de los derechos de carácter privado, porque en nuestro ordenamiento jurídico la titularidad de derechos no se vincula necesariamente a la nacionalidad o a la vecindad civil. También lo es para el caso en que la jurisdicción actúa como garantía frente a la actuación de los poderes públicos, puesto que los extranjeros, se encuentren o no en territorio español, pueden ser destinatarios (y sujetos pasivos) de la actuación de las Administraciones Públicas y, por ello, se les debe reconocer el derecho a someter a control de legalidad, ante los órganos públicos independientes que integran la jurisdicción.

Es más. Aunque justifiquemos la atribución del derecho a la tutela judicial al individuo en la necesidad de ofrecer a los sujetos que son titulares de derechos medios para poder hacerlos efectivos por cauces pacíficos, la extensión subjetiva del derecho a la tutela judicial va más allá aún, pues la posibilidad de acceder a la jurisdicción debe reconocerse a todos los individuos, sean o no titulares de derechos y obligaciones: la titularidad de la tutela judicial no se condiciona a la efectiva titularidad de derechos sino, de otro modo, a la $a p-$ titud para poder ser titular de derechos y obligaciones. Es decir, a la personalidad jurídica. Otra cosa es que, finalmente, la decisión final del proceso deniegue el derecho solicitado o afirmado: precisamente ese es el objeto de la jurisdicción. Lo contrario conduciría a una petición de principio, habida cuenta de que el reconocimiento del derecho a la tutela judicial tendría como condición el reconocimiento de la efectiva titularidad de derechos (lo que sólo puede hacer el juez).

Lo relevante es, en resumidas cuentas, no la titularidad efectiva, sino la aptitud para ser titular de derechos y obligaciones. Ello nos coloca en el lugar oportuno a la hora de buscar respuesta a la pregunta de si los extranjeros 
tienen o no el derecho a la tutela efectiva del Art. 24.1 de la CE. La respuesta se obtiene respondiendo a la pregunta de si los extranjeros tienen aptitud para ser titulares de derechos y obligaciones en España ${ }^{13}$. La contestación es obvia en el caso de los extranjeros que se encuentren en España de forma regular, pero, a nuestro entender, también lo es para quienes se encuentren de forma irregular, en la medida en que sean capaces de actuar válidamente en el tráfico jurídico y concertar con terceros a través de su voluntad la celebración de negocios jurídicos: pueden contratar y ser contratados, pueden obligarse y ser titulares de obligaciones válidamente constituidas. Incluso en el caso de no ser titulares de esos derechos subjetivos privados, el mero sometimiento a la autoridad del Estado implica el reconocimiento del derecho a acudir a la jurisdicción para la revisión de las resoluciones administrativas que les afecten. Es la personalidad, obtenida de acuerdo con las exigencias del Código civil, y no la vecindad, lo que da el derecho a la tutela, entendido éste último como derecho a la justicia, razón que sin duda se encuentra en la afirmación del derecho a la tutela judicial como parte del derecho a la dignidad de las personas.

Además, la peculiaridad del derecho a la tutela judicial, entendido conforme con la doctrina constitucional consolidada como el "derecho fundamental a obtener una resolución judicial fundada en derecho", implica el que se garantice incluso cuando sea ejercitado por quien carece de capacidad para ser parte, pues el mero hecho de dictar una resolución del tribunal de no admisión de una demanda o escrito por falta de personalidad es, formalmente, una respuesta jurisdiccional al que lo interpone, con el que se ejerce de modo efectivo, conforme los parámetros de la doctrina constitucional, el derecho a la tutela judicial dirigida a quien, a priori, no es titular del derecho ${ }^{14}$.

Lo expuesto sirve de marco justificativo de la doctrina del Tribunal Constitucional sobre la titularidad del derecho a la tutela judicial efectiva de los extranjeros. Sobre el particular, la STC 99/1985, que resolvía un recurso de amparo contra sentencia que no admitía una querella por falso testimonio por no contar con la debida autorización del tribunal ante el que se formuló la declaración, afirmó (F. J. $2^{\circ}$ ), a propósito de la extranjería, "que ésta es irrelevante en relación con el derecho constitucional controvertido, que en este caso (al margen de otras alegaciones improcedentes) es el derecho fundamental a una tutela judicial efectiva». Esta doctrina concreta, en relación con el derecho a la tutela judicial efectiva, enlaza con la emanada de la STC 107/1984, primera de las sentencias dictadas por el Alto Tribunal en relación con la titularidad de los derechos fundamentales por los extranjeros. A partir de esta sentencia ha construido el Tribunal Constitucional una doctrina sobre

13 Un tema recientemente tratado con extensión, entre otros, en la obra colectiva Los derechos de los inmigrantes en España (coord. E. AJA), Valencia, Tirant lo Blanch, 2009).

14 Sobre este particular, vid la STC 236/2007, primera que reconoce el derecho a la tutela judicial de los extranjeros irregulares en España. 
los derechos de los extranjeros, cuyos elementos básicos se han mantenido vigentes hasta hoy y en la que se distinguen varios tipos de derechos en relación a su aplicación a los extranjeros ${ }^{15}$.

- En el primer grupo se incluyen aquellos derechos que corresponden a los extranjeros por propio mandato constitucional y no resulta posible un tratamiento desigual respecto de los españoles, puesto que gozan de ellos en condiciones plenamente equiparables a los españoles. Estos derechos son los que "pertenecen a la persona en cuanto tal, no como ciudadano (...) aquellos que son imprescindibles para la garantía de la dignidad bumana que, conforme al artículo 10.1 de nuestra Constitución, constituye fundamento del orden político español " ${ }^{16}$. El Tribunal no da una lista de ellos pero sí menciona algunos incuestionables, "el derecho a la vida, a la integridad fisica y moral, a la intimidad, la libertad ideológica, el derecho a la libertad y a la seguridad, y el derecho a no ser discriminado por razón de nacimiento, raza, sexo, religión o cualquier otra condición o circunstancia personal o social" y, desde la STC 236/2007, también el derecho a la tutela judicial efectiva y el derecho instrumental a la asistencia jurídica gratuita ${ }^{17}$. Todos ellos han sido reconocidos expresamente por este Tribunal como pertenecientes a la persona en cuanto tal, pero no constituyen una lista cerrada y exhaustiva. El Tribunal considera que el grado de conexión de un concreto derecho con la dignidad de la persona habrá de determinarse a partir de su contenido y siguiendo para ello la Declaración Universal de los Derechos Humanos y los acuerdos y tratados internacionales a los que remite el propio artículo 10.2 CE. La cuestión problemática es determinar qué se entiende por derechos que nacen de la dignidad humana ${ }^{18}$.

15 GUTIÉRREZ GUTIÉRREZ, I., "Los derechos fundamentales de los extranjeros en la Constitución y en las Leyes españolas", Boletín de la Facultad de Derecho, UNED, n. ${ }^{\circ} 22$, 2003, págs. $13-26$.

16 SSTC $107 / 1984$, F.J. $3^{\circ}$ y $95 / 2000$, F.J. $3^{\circ}$.

17 Este segundo reconocido inicialmente por la LO 4/2000 en su Art. 22, y cuyos términos han sido ampliados, conforme con la doctrina constitucional, tras la reforma operada por la LO 2/2009, en los términos que se verán.

18 HABËRLE, P., El Estado constitucional: Proceso constituyente. Derechos fundamentales. Dignidad humana. Libertad cultural. Trabajo y propiedad. Interpretación y comparación de textos constitucionales. Influencias en América. Reforma de la Constitución. Estado constitucional cooperativo, Astrea, Buenos Aires, 2007; DOMÍNGUEZ GARCÍA, F., "Dignidad humana, tratados internacionales y derechos de los extranjeros: comentario a las SSTC 236/2007, 259/2007 y concordantes", Revista Jurídica de Catalunya, n. ${ }^{\circ}$ 4, 2008, págs. 1153-1166; GUTIÉRREZ GUTIÉRREZ, I., Dignidad de la persona y derechos fundamentales, Madrid, Marcial Pons, 2005; JIMENA QUESADA, L., Dignidad humana y justicia universal en España, Cizur Menor (Navarra), ThompsonAranzadi, 2008; DE KONINCK, T., De la dignidad humana, Madrid, Dykinson, 2006; PECES-BARBA MARTÍNEZ, G., "Reflexiones sobre la evolución histórica y el concepto de dignidad humana", Desafíos actuales a los derechos humanos: la violencia de género, la inmigración y los medios de comunicación, Madrid, Dykinson, 2005, págs. 15-36, RUIZ MIGUEL, F., “La dignidad humana: historia de una idea", Estudios de teoria del Estado y derecho constitucional en honor de Pablo Lucas Verdú, (Dirs. Raúl Morodo y Pedro de Vega), Madrid, Servicio de Publicaciones, Facultad de Derecho, Universidad Complutense de Madrid, 2001, págs. 1887-1909. 
- Un segundo grupo está constituido por aquellos derechos que la Constitución reconoce expresa y directamente a los extranjeros, que son aquellos a los que se refiere su Art. 13.1. A primera vista considera la jurisprudencia citada que el legislador no puede negar tales derechos a los extranjeros, aunque sí puede establecer condicionamientos adicionales respecto de su ejercicio por parte de aquéllos, si bien ha de respetar, en todo caso, las prescripciones constitucionales ${ }^{19}$, lo que implica que la regulación habrá de respetar, en todo caso, el contenido esencial del derecho.

En un principio se consideró, en interpretación literal de la norma constitucional, que el Art. 13.1 concibe derechos fundamentales de configuración legal, una suerte de desconstitucionalización de los derechos, lo que tendría como consecuencia el que no estarían sometidos a las garantías del Art. 53.1 de la CE; la doctrina constitucional evolucionó rápidamente en el sentido de que los derechos del Art. 13.1 de la CE no son meros derechos de configuración legal, sino derechos que se imponen al legislador, aunque sobre ellos se conserva cierto poder de modulación ${ }^{20}$.

- El tercer grupo lo integran aquellos derechos que no atribuidos directamente por la Constitución a los extranjeros, pueden extenderse por la ley a los no nacionales, aunque no sea necesariamente en idénticos términos que los españoles. Se trata de derechos en los que es admisible un tratamiento diferenciado entre españoles y extranjeros, en virtud de lo que dispongan los tratados y las leyes que los regulen, siempre que en su aplicación no se vulnere el contenido esencial del derecho de que se trate ${ }^{21}$. En este grupo, el Tribunal Constitucional incluye el derecho al trabajo, el derecho a la salud, el derecho a percibir una prestación de desempleo y, también con matizaciones, el derecho de residencia y desplazamiento en España ${ }^{22}$. Para el Tribunal, las condiciones de ejercicio que el legislador establezca respecto de los derechos y libertades de los extranjeros en España "sólo serán constitucionalmente válidas si, respetando su contenido esencial (art. 53.1 CE) se dirigen a preservar otros derechos, bienes o intereses constitucionalmente protegidos y guardan adecuada proporcionalidad con la finalidad perseguida".

- Finalmente existe un último grupo de derechos, que son aquellos en los que no es posible el acceso a los extranjeros y que son los declarados en el propio artículo 13.2 del texto constitucional, con la salvedad que el mismo contiene: "Solamente los españoles serán titulares de los derechos reconocidos en el art. 23, salvo lo que, atendiendo a criterios de reciprocidad, pueda establecerse por tratado o ley para el derecho de sufragio activo y pasivo en las elecciones municipales".

19 STC $236 / 2007$, F.J. $4^{\circ}$.

20 En el primer sentido, la STC 107/1984; en el segundo, la STC 115/1987.

21 En cuanto no son derechos imprescindibles para la garantía de la dignidad humana (...) es pues lícito que las leyes y tratados modulen el ejercicio de esos derechos en función de la nacionalidad de las personas, introduciendo tratamientos desiguales entre españoles y extranjeros" (STC 94/1993, de 22 de marzo, F. J. $4^{\circ}$ ).

22 STC $236 / 2007$, F. J. $4^{\circ}$. 
En resumen, al extender la titularidad de los derechos y libertades fundamentales a los extranjeros, el Tribunal Constitucional efectúa una graduación de derechos que afecta a cuestiones tales como la sujeción al régimen de garantías del Art. 53 de la CE, la posibilidad misma de la titularidad del derecho por el extranjero o la posibilidad de modulación de su alcance por el legislador ordinario. Desde este punto de vista, el derecho a la tutela judicial efectiva pertenecería el grupo de los derechos de calidad reforzada, pues, con buen criterio lógico, se vincula con los derechos derivados del deber de respeto de la dignidad humana (Art. 10.1 de la CE). De ello se desprenden una serie de consecuencias legales, que ahora nos interesa destacar. Singularmente, su inmediata aplicabilidad sin necesidad de desarrollo legislativo y lo que es todavía más interesante - el hecho de que su ejercicio se realizará "en condiciones plenamente equiparables a los españoles" ${ }^{23}$.

La cuestión tiene relevancia, puesto que se eliminan las diferencias de tratamiento legal entre los españoles y los extranjeros, lo cual es coherente con el criterio interpretativo general que entiende que los extranjeros ejercitan los derechos que les reconoce la ley en condiciones de igualdad con los españoles (Art. 3 de la LO 4/2000). Sin embargo, han existido y aún existen determinadas diferencias en el desarrollo legislativo del derecho a la tutela judicial entre extranjeros y españoles. La cuestión que nos planteamos en este punto es en qué medida son conformes con el derecho a la tutela judicial esas desigualdades en la esfera procesal, con limitación de las posibilidades de actuación de los extranjeros con respecto a lo que la ley reconoce a favor de los españoles, si siendo la tutela judicial un derecho derivado de la dignidad humana, no acepta a priori desigualdad de trato entre unos y otros.

La justificación de esas desigualdades no puede separarse de la propia idiosincrasia de la actividad jurisdiccional. Aunque del derecho a la tutela judicial se disfrute ipso iure a partir del Art. 24.1 de la CE, no se ignora que la administración de Justicia, en toda su extensión, exige un desarrollo legislativo contenido en las normas de procedimiento, precisa una intervención del legislador ordinario que, en desarrollo del derecho constitucional, establezca ese modelo de conductas del tribunal y de las partes, siempre con la condición de respeto del contenido esencial del derecho a la tutela judicial. Ello, sumado al hecho del carácter multiforme del derecho a la tutela judicial, en cuyo seno se incorporan gran cantidad de condicionantes para el legislador en diferentes materias de naturaleza procesal (derecho a la prueba, derecho a los recursos, motivación de las sentencias, ejecución forzosa, derecho a la asistencia letrada, non bis in idem procesal, por citar algunos), no facilita la labor de legislador a la hora de brindar un tratamiento uniforme a los nacionales y a los extranjeros en materia de tutela judicial.

En primer lugar, no extraña la existencia de determinadas normas procesales destinadas exclusivamente a los extranjeros (en la propia LO 4/2000), y 
ello no tiene por qué entenderse disconforme con las exigencias de tratamiento uniforme, en la medida en que esas normas pertenecen al ámbito particular de la tutela de los derechos de los extranjeros: pensamos, por ejemplo, en las normas de los artículos que contemplan actuaciones específicas de los extranjeros en los procedimientos relacionados con los expedientes de extranjería. En puridad, la regulación de una actuación procesal concebida exclusivamente para su aplicación por un extranjero o nacional no implica un tratamiento diferenciado desde el punto de vista de los Arts. 14 y 24.1 de la $\mathrm{CE}$, puesto que el Derecho procesal es, ante todo, instrumental, por lo que no debe ser contrario a la tutela judicial que la ley procesal, en función de la naturaleza y contenido de las pretensiones en juego en el proceso, prevea actuaciones procesales diferenciadas para el extranjero.

\section{ALGUNOS CASOS DE TRATAMIENTO DIFERENCIADO A LOS EXTRANJEROS Y A LOS ESPAÑOLES, DESDE EL PUNTO DE VISTA DE LA TUTELA JUDICIAL EFECTIVA}

Existen, sin embargo, algunos casos en que la conclusión puede no ser tan rotunda, pues se trata de normas procesales generales que establecen una desigualdad de trato al español y al extranjero no sustentada en la especialidad del objeto procesal. A continuación pasamos revista a algunos de estos casos.

\section{A) La CaUCión de arRaigo EN JUICIO}

Ocurría así, por ejemplo, con la anterior Ley de Enjuiciamiento Civil (LEC de 1881), con la denominada "caución de arraigo en juicio" (cautio judicatum solvi). La caución de arraigo en juicio constituía un óbice procesal consistente en el deber que tenían los demandantes extranjeros de afianzamiento de las resultas del proceso ${ }^{24}$, con el fin de responder de las costas procesales. Se partía de la base de que el extranjero que pretendiera demandar ante los tribunales españoles, con independencia de que tuviera o no bienes en España, podría no disponer de patrimonio suficiente para responder de una eventual condena en costas, por lo cual podría ser exigible la prestación de la caución — siempre de acuerdo con las exigencias del principio de reciprocidad y en la forma en que fuera exigible a los españoles en el país de origen-. En caso de no hacerlo, el demandado podía alegar el defecto como excepción procesal (excepción dilatoria del Art. 534 de la LEC de 1881).

24 Utilizando la expresión de GUASP, J., Comentarios a la Ley de Enjuiciamiento Civil, Madrid, Aguilar, t. II, vol. I, 1945, pág. 309. Sobre esta institución, vid. El trabajo clásico de ALCALÁZAMORA CASTILLO, N., "La excepción dilatoria de arraigo del juicio", Estudios de Derecho Procesal, 1934, págs. 507 y ss. 
La figura de la cautio judicatum solvi aparecía muy disminuida por aplicación de numerosos convenios internacionales suscritos por España, y la Ley de Enjuiciamiento Civil de 2000 derogó la norma contenida en el Art. 534 de la vieja LEC y, con ello, acogió una disposición del Tratado de la Haya sobre Procedimiento Civil, de 1 de enero de 1954, que suprime la necesidad de prestar esa caución entre los países signatarios o ratificantes. Asimismo, recoge una línea jurisprudencial fijada por el Tribunal Supremo (STS1 ${ }^{a}$ de 31 de octubre de 1989), que considera el Art. 534 de la LEC de 1881 excepción procesal anacrónica e, incluso, discriminatoria, ha de ser objeto de una interpretación restrictiva, entre tanto no se produzca, de lege ferenda, su tal vez aconsejable desaparición ${ }^{25}$.

En esta misma línea se pronunció el Tribunal de Justicia de las Comunidades Europeas en sus sentencias de 20 de marzo de 1997 (TJCE 1997 \62 des Hayes), 1 julio 1993 (TJCE 1993\111, Hubbard), al considerar contrario al Art. 6 del Tratado de la Comunidad Europea que un Estado miembro exija la constitución de una cautio iudicatum solvi por un nacional de otro Estado miembro que haya instado, ante uno de los órganos jurisdiccionales civiles del primer Estado miembro, una acción judicial contra uno de sus nacionales, cuando una obligación semejante no pueda imponerse a los nacionales de este Estado que no posean en él ni bienes ni domicilio, en una situación en que la acción tenga conexión con el ejercicio de las libertades fundamentales garantizadas por el Derecho comunitario ${ }^{26}$. En el TEDH, no obstante, sólo hemos encontrado una decisión de inadmisión, por entender que la prestación de la caución no impidió en el caso al reclamante el ejercicio de su derecho (REQUETE $\mathrm{N}^{\circ} 7973 / 77$ X. v. Suecia) 28 de febrero de 1979, junto con el compromiso del estado sueco de reformar la ley y suprimir la cautio judicatum solvi.

\section{B) El EMBARGo PREVENTIVO}

Otra desigualdad de trato se producía, con la vieja LEC de 1881, en la regulación del embargo preventivo. El Art. 1400 introducía, entre los casos en que procedía ordenar el embargo preventivo, que el deudor/demandado fuera un "extranjero no naturalizado" en España. Se trataba, en puridad, de una presunción legal del periculum in mora, esto es, en el reconocimiento de

25 En idéntico sentido, las SSTS $3^{\text {a }}$ de 9 de junio de 1988 y de 29 de septiembre de 1993, que consideraron incompatible el arraigo en juicio con el derecho a la tutela judicial de los extranjeros (ver también SAP de 20 de marzo de 2005).

26 En parecidos términos, la STJUE $1997 \backslash 196$ de 2 de octubre de 1997, Saldanba y MTS. Vid asimismo la STJCE de 26 de septiembre de 1996, comentada por FONT SEGURA, A., "La cautio iudicatium solvi ante el derecho comunitario: sentencia del TJCE de 26 de septiembre de 1996, data selecta Aktiebolag, R. Forsbert C. MSL Dynamics Ltd. (Asunto C.43/95)", Justicia: revista de derecho procesal, n. 2 Año 1997, Barcelona, José María Bosch, 1981, págs.505-529. 
que los extranjeros no naturalizados presentan un mayor riesgo de sustraerse al cumplimiento de la condena futura que el natural no.

La vigente Ley de Enjuiciamiento Civil de 2000 suprime esa exigencia legal para acordar el embargo preventivo o cualquier otra medida cautelar, pero eso no significa que el solicitante no pueda justificar el peligro de mora procesal, como presupuesto para la adopción de la medida cautelar, en las circunstancias personales del deudor demandado, entre las cuales, según las circunstancias del caso, podría encontrarse la condición de extranjero: en nuestra opinión, una opción que puede escogerse no de modo aislado, sino asociada a otras circunstancias de hecho, tales como su vecindad legal o la existencia en España de bienes con los cuales hacer frente a una eventual condena. El Art. 728 de la LEC, en este punto, no contraviene lo dispuesto en la norma derogada, sino que modifica el supuesto de hecho y da más margen al tribunal para que valore los riesgos asociados al periculum in mora ${ }^{27}$.

\section{C) CONSIDERACIÓN ESPECIAL DEL DERECHO A LA ASISTENCIA JURÍDICA GRATUITA}

\section{c.1. Planteamiento}

Otro caso en el que se ha puesto de manifiesto la vinculación que existe entre el derecho a la tutela judicial de los extranjeros y el derecho de igualdad, en la medida en que la doctrina constitucional exige, por su condición de derecho derivado directamente de la condición de persona (vinculado, como hemos visto, al Art. 10.1 de la CE), un trato igualitario.

En su regulación original, la Ley de Asistencia Jurídica Gratuita (Ley 1/1996) daba un tratamiento diferenciado a los españoles y a los extranjeros, en los casos de reconocimiento judicial del derecho de asistencia jurídica gratuita (antiguo beneficio de pobreza o, tras la reforma de la LEC de 1881 por la Ley 34/1984, beneficio de justicia gratuita) ${ }^{28}$. En estos casos, la asistencia jurídica implica el reconocimiento de una serie de derechos dentro del proceso para el beneficiario que justifique la carencia de recursos para litigar, en los términos de la ley, que se traduce en la exoneración del pago de determinados derechos económicos (Art. 6 de la Ley 1/1996): exención de pago de depósitos, inserción gratuita de anuncios y edictos en periódicos oficiales, la obtención gratuita de copias y documentos, la reducción (en un 80\%) de los

27 Vid AP Granada, sec. 4a A $17-12-2002$, n 183/2002, rec. 487/2002.

28 Sobre la inclusión de este derecho en el ámbito del Convenio Europeo de Derechos Humanos, vid. ARANGÜENA FANEGO, C., "Exigencias en relación con el derecho de defensa: el derecho a la autodefensa, a la defensa técnica y a la asistencia jurídica gratuita [Art. 6.3.c) CEDH], La Europa de los derechos: el convenio europeo de derechos humanos, (Coords. J. Garcia Roca, P. Santolaya), Madrid, Centro de Estudios Políticos Constitucionales, 2005, págs. 389-405. Sobre la asistencia jurídica, en general, BACHMAIER WINTER, L., La asistencia jurídica gratuita, Granada, Comares, 1999. De gran interés es el estudio de CUARTERO RUBIO, M. V., "Inmigración ilegal y justicia gratuita", Derecho privado y Constitución, n. ${ }^{\circ}$ 18, 2004, págs. 143-169. 
gastos por obtención de copias y testimonios notariales y de certificaciones y notas de registros públicos. También, la gratuidad de determinados servicios de asesoramiento legal (previos al proceso, o para analizar la sostenibilidad de la pretensión, asistencia al detenido o preso en el proceso penal) y la asistencia letrada y la representación técnica gratuitas, a través de abogado y procurador de oficio, cuando su actuación sea preceptiva, conforme a la ley.

El Art. 2.1 a) de la Ley 1/1996, reguladora del derecho entendía como posibles titulares del derecho, cuando acreditasen insuficiencia para litigar, a los "ciudadanos españoles, a los nacionales de otros estados de la Unión Europea, y a los extranjeros que residan legalmente en España". Esta limitación no se daba, en el propio Art. 2 (letra e), para litigar en el ámbito penal, a los extranjeros que acreditasen insuficiencia de recursos económicos para litigar, "aun cuando no residan legalmente en el territorio español". En el caso de la asistencia al detenido o preso, se presume que el detenido carece de los recursos para litigar (para asegurar la asistencia letrada en el plazo constitucional de detención), sin perjuicio de que, de no carecer finalmente de los recursos, la actuación del letrado de oficio devengue finalmente el derecho a percibir honorarios.

Por su lado, en el orden contencioso-administrativo el apartado f del Art. 2 de la Ley 1/1996, antes de la reciente Ley 12/2009, de 30 de octubre, reguladora del derecho de asilo y de la protección subsidiaria, reconocía a los extranjeros no residentes legalmente en España el derecho a disfrutar de asistencia letrada y defensa y representación técnica en los procedimientos de asilo. En el orden jurisdiccional laboral, la situación de españoles y extranjeros (en todos los casos) es equiparable, de acuerdo con la dicción del Art. 2 d) de la Ley 1/1996, y en la medida en que el extranjero pudiera gozar de la consideración de trabajador, una situación que se extiende a éstos cuando deban defender sus derechos en el proceso concursal o ante la jurisdicción contencioso-administrativa (tras la reforma de la Ley 16/2005, a la que más adelante nos referimos).

Salvando el hecho, per se relevante, de que s.e.u.o. es la primera vez que el legislador ordinario equipara, en sede procesal, los derechos de españoles y extranjeros no residentes legalmente en España en la esfera jurisdiccional, no se oculta que en la regulación del ámbito personal de aplicación del nuevo régimen legal de la asistencia jurídica gratuita contiene una diferencia de trato entre los españoles y los extranjeros, particularmente evidente en el criterio general de titularidad del derecho a litigar gratuitamente, que es el aplicable en el orden jurisdiccional civil. En nuestra opinión, la expresión que empleaba el Art. 2, e y f, en relación con los órdenes penal y contencioso administrativo, de los "extranjeros no residentes legalmente en España", se refiere a todo aquél extranjero que carezca de visado de residente, se encuentre en situación regular (por ejemplo, como transeúnte o con visado de turista) o se encuentre en situación irregular.

La desigualdad dio lugar al planteamiento de un recurso de inconstitucionalidad por el defensor del pueblo, resuelto por la STC 95/2003, anterior- 
mente citada ya, en el que el Alto tribunal declara que el inciso "legalmente" incluido en el apartado a), artículo 2 de la Ley 1/1996 es inconstitucional reconociendo así el derecho a la asistencia jurídica gratuita a todo extranjero que quiera litigar ante los tribunales españoles, ya se encuentre en España o en el extranjero. Esta misma sentencia, avala la interpretación apuntada de que la expresión "no residentes en España legalmente" se refiere a la situación fáctica de residente, y no a la autorización administrativa para ello. La STC 95/2003 censura del mismo modo que se reconozca la asistencia gratuita en el orden administrativo a los procesos de asilo, pero no así en otros procedimientos que puedan depara la expulsión o devolución del extranjero, en los que puede ser preceptiva la asistencia de letrado y/o procurador.

La ratio decidendi del Tribunal Constitucional vincula el derecho a la tutela judicial con el derecho a la gratuidad de la justicia, pues este segundo deriva no del Art. 24.1 de la CE, sino del art. 119 de la CE, en el Título VI constitucional, al regular el Poder Judicial, entendiendo la sentencia, de conformidad con la doctrina del propio Tribunal, que aunque el derecho derivado del Art. 119 es de configuración legal — pues es al legislador a quien compete establecer los límites y modular su contenido (SSTC 16/1994; 182/2002) - , la vinculación entre la gratuidad y el derecho de acceso a los tribunales (integrado en el contenido del Art. 24.1 de la CE), opera como límite para el legislador ordinario, de suerte que la conformación legal del proceso gratuito no puede rebasar un núcleo esencial, que es aquel a partir del cual la carencia de recursos económicos opera como óbice para acceder a los tribunales. Y, por otro lado, recuerda que, como derecho vinculado a la dignidad de la persona, debe reconocerse en términos de igualdad a los españoles y a los extranjeros ${ }^{29}$.

29 La sentencia tuvo tres votos particulares (Sres. Conde, García-Calvo y Rodríguez Zapata), en los cuales, grosso modo, se discrepa de la tesis mayoritaria del Tribunal favorable a la igualdad entre españoles y extranjeros a la hora de disfrutar de la tutela judicial, tesis que en absoluto se entiende incontrovertible; los votos particulares abogan por la posibilidad de modular en la ley la incidencia del derecho fundamental, lo que en cierta medida contradice la doctrina general mantenida por el Tribunal (o se afirma que la regulación de la asistencia jurídica gratuita no se vincula a la tutela judicial). Se afirma en ellos también que la sentencia es "preocupante", pues al margen de sus efectos, se está actuando como legislador positivo (una duda siempre presente en toda sentencia interpretativa).

Como argumento de autoridad, se cita la doctrina emanada de la STC 12/1998, en la que se desestimó la cuestión de inconstitucionalidad planteada sobre la posibilidad de denegar el derecho a quienes trataran de llevar a los Tribunales pretensiones insostenibles en el marco de tal libertad de configuración normativa del derecho consagrado en el art. 119 CE, afirmando de modo expreso que no es contrario a la Constitución la instauración de un límite legal al libre ejercicio del derecho de acceso a la jurisdicción por parte de los ciudadanos que carecen de recursos económicos suficientes para litigar. Este límite, se ha dicho, está basado en una finalidad constitucional legítima, razonable y proporcionada. Tal limitación —que recordemos está relacionada con el derecho de acceso al proceso- se encuentra entre los que legítimamente puede perseguir el legislador a la hora de limitar el libre ejercicio del derecho de acceso a los órganos jurisdiccionales".

A nuestro entender, este último argumento del segundo voto particular es falaz, puesto que no se discute aquí si el legislador está o no en condiciones de modular el ejercicio del derecho a 
c.2. Modificaciones de la legislación ordinaria de extranjería, en relación con la asistencia jurídica gratuita de los extranjeros, y control de constitucionalidad de las nuevas leyes

Con anterioridad a la STC 95/2003, la Ley 4/2000 había introducido modificaciones ya relativas a la asistencia jurídica de los extranjeros. El Art. 20 de la Ley Orgánica 4/2000, en su versión original, reconocía el derecho de los extranjeros que se hallaren en España a la asistencia letrada de oficio en los procedimientos administrativos o judiciales que pudieran llevar a la denegación de su entrada o a su expulsión o salida obligatoria del territorio español y en todos los procedimientos en materia de asilo, el derecho a la asistencia de intérprete si no comprenden o hablan la lengua oficial que se utilice. Y extendía genéricamente el derecho de asistencia jurídica gratuita a todos los extranjeros residentes en España o inscritos en el Padrón Municipal que acreditasen insuficiencia de recursos para litigar, en iguales condiciones que los españoles.

El precepto, renumerado por la Ley Orgánica 8/2000, fue declarado inconstitucional en lo referente a la exigencia de residencia para ser beneficiario de la asistencia jurídica gratuita por la doctrina comenzada por la STC 236/2007. El nuevo texto del artículo extendió el derecho a la asistencia jurídica gratuita a los procesos administrativos que pudieran conducir a la denegación de entrada, devolución o expulsión, a todos los extranjeros, sin condiciones, pero en el resto de los procesos, se condicionaba el disfrute del derecho a tener residencia en España.

La STC 236/2007 declaró inconstitucional condicionar el reconocimiento y el ejercicio del derecho de asistencia jurídica gratuita (junto con otros: reunión, sindicación y manifestación) a los extranjeros inmigrantes en nuestro país a la previa obtención o posesión de autorización de estancia o residencia en España. El argumento del que parte la sentencia es que el Art. 13.1 de la $\mathrm{CE}$, del que parte la atribución de derechos constitucionales a los extranjeros, se refiere a todos ellos, por contraposición a las personas de nacionalidad española, a pesar de que aquéllos puedan encontrarse en España en situaciones jurídicas diversas, abundando en los argumentos ya expuestos sobre la imposibilidad de establecer limitaciones por vía legal a los derechos dependientes de la dignidad humana, marcando diferencias entre los españoles y los extranjeros.

Esa es la razón por la cual se declaró inconstitucional en el Art. 22.2 de la Ley Orgánica 4/2000, en la redacción dada por la Ley Orgánica 8/2000, la in-

la tutela judicial, algo que es notorio desde el momento en que la tutela judicial requiere, para ser prestada, de procesos judiciales y que éstos se regulan en las leyes por el legislador ordinario: toda norma procesal es, en consecuencia, una modulación del derecho a la tutela judicial, que restringe en mayor o menor medida, en cada caso, las posibilidades de actuación y el modo de ejercicio de los derechos de los litigantes. Lo que se discute aquí, de otro modo, es si es justificable un trato diferenciado a un español y a un extranjero (sea cual sea el estatuto jurídico con el que se encuentre en España), a la hora de desarrollar, en la ley, el derecho a la tutela judicial, lo que, de nuevo, vincula el asunto analizado con el derecho de igualdad. 
clusión del adjetivo residentes ${ }^{30}$. Tanto la Ley 12/2009 como la LO 2/2009, introducen la doctrina constitucional en el ámbito de los procedimientos de asilo y de extranjería: la primera, en su art. 16.2, extiende el derecho a litigar gratuitamente en procedimientos de asilo en lo que se refiere a la formalización de la solicitud y a toda la tramitación del procedimiento, y que se prestará en los términos previstos en la legislación española en esta materia, así como derecho a intérprete en los términos del artículo 22 de la Ley Orgánica 4/2000, incluso en los casos de solicitud en puesto fronterizo.

Por su parte, la nueva redacción dada al art. 22 de la LO 4/2000 por la LO 2/2009, equipara a nacionales y extranjeros en materia de justicia gratuita, en todo tipo de procedimientos (párr. 1). En procedimientos administrativos que puedan llevar a su denegación de entrada, devolución, o expulsión del territorio español y en todos los procedimientos en materia de protección internacional, así como a la asistencia de intérprete si no comprenden o hablan la lengua oficial que se utilice, se reconoce el derecho a la asistencia letrada, que será gratuita cuando carezcan de recursos económicos suficientes según los criterios establecidos en la normativa reguladora del derecho de asistencia jurídica gratuita. Se recoge en la ley así la doctrina constitucional, si bien el legislador recuerda, en la exposición de motivos, que no nos encontramos ante un derecho de carácter absoluto, por lo que sería plenamente legítimo el establecimiento de límites legales al derecho en el caso de litigantes extranjeros. El derecho se reconoce específicamente en el caso de extranjeros internados (art. 62 bis) y en el del procedimiento preferente, del art. 63 de la LO 4/2000.

\section{D) EJERCICIO DE LA ACCIÓN POPUlAR, FIANZA EN LA QUERELLA Y DERECHO AL USO DE INTÉRPRETES}

La tesis favorable a la necesidad de establecer un tratamiento idéntico a los extranjeros y a los españoles cuando de la tutela judicial cuenta con algunas excepciones, de acuerdo con el desarrollo en la legislación procesal del derecho a la tutela judicial. Nos referimos en concreto a dos supuestos, sin perjuicio de la existencia de otros equivalentes en nuestro derecho, ambos referentes al ejercicio de la acción penal por parte de ciudadanos extranjeros. Se trata del Art. 270 de la Ley de Enjuiciamiento Criminal, el cual restringe el ejer-

30 Aunque en sus alegaciones, el Abogado del Estado afirmó que, por aplicación sistemática con la Ley 1/1996, y aplicación de la norma más favorable al ejercicio del derecho, era innecesaria la declaración de inconstitucionalidad. Según este razonamiento, la doctrina emanada de la STC 95/2003 se incorporó a la Ley 1/1996 por la Ley 16/2005, la cual, en lo que aquí interesa, había suprimido el requisito genérico del Art. 2 a) de necesidad de residencia legal, exigiendo tan sólo que el extranjero "se hallare en España", y extendió en el orden administrativo la asistencia jurídica y defensa y representación gratuitas a los procedimientos administrativos previos y contencioso administrativos de los cuales pueda resultar la expulsión, devolución prohibición de entrada en España de un extranjero. 
cicio de la acción popular a los españoles. Se prohíbe, pues, la posibilidad de ejercer la acción penal a los extranjeros, salvo cuando se trate del ofendido o perjudicado por el delito (esto es, constituyéndose como acusación particular), eso sí, previa prestación en este segundo caso de fianza para responder (Art. 280 de la LECrim) de las "resultas del juicio" (Art. 281, II de la LECrim).

El Art. 125 de la CE atribuye la legitimación extraordinaria convertirse en actor popular a los "ciudadanos", no a las personas, por lo cual el reconocimiento del derecho a los extranjeros sólo sería aceptable previo reconocimiento de su ciudadanía española, cuestión ésta susceptible también de interpretación. En cuanto a la exigencia de fianza a los extranjeros no ha sido objeto de tratamiento por el Tribunal Constitucional, que sí ha declarado constitucional la desigualdad de tratamiento, en cuanto a la exigencia de fianza, del ofendido por el delito y del no ofendido ${ }^{31}$. Con todo y con ello, la especialidad del Art. 281, II de la LECrim es de naturaleza semejante a la cautio judicatum solvi civil, analizada con anterioridad, erradicada de nuestro ordenamiento procesal civil y declarada contraria a las exigencias del Art. 6 del Tratado de la Comunidad Europea por las reseñadas decisiones del Tribunal de Justicia Comunitario.

Otro caso de posible desigualdad entre españoles y extranjeros, en el seno del proceso, lo constituye a priori la posibilidad por parte de estos de disponer de intérprete, en caso de no conocer la lengua oficial que se utilice (Arts. 22.2, 62 bis y 63 de la Ley Orgánica 4/2000). La necesidad de intérprete conecta directamente con el derecho de defensa de las personas, y, por mucho que implique un tratamiento diferente, no significa que de ello se deduzca un menoscabo de la posición jurídica de los españoles o extranjeros que sí conozcan la lengua utilizada, aunque sí suponga, a nuestro entender, que, como toda regla general, el principio de tratamiento igualitario entre españoles y extranjeros en materia de tutela judicial puede ser modulado por el legislador si concurren razones que lo justifiquen. En este punto cabe recordar que la jurisprudencia constitucional ha avalado el uso del intérprete en diferentes decisiones: como vulnerador del derecho a la tutela del extranjero ${ }^{32}$, aunque sea exigible que realmente se produzca indefensión ${ }^{33}$.

La doctrina constitucional nos conduce, sin embargo, a negar que nos encontremos ante un supuesto de desigualdad de trato entre españoles y extranjeros. Por otra parte, el Tribunal Constitucional ha sostenido también la necesidad del intérprete por exigencias del derecho de defensa para los españoles que no conozcan el castellano, partiendo del razonamiento de que no cabe objetar que el castellano es la lengua española oficial del Estado y que todos los españoles tienen el deber de conocerla (art. 3.1 CE), ya que lo que se valora es un hecho (la ignorancia o conocimiento insuficiente del castellano) en cuanto afecta al ejercicio de un derecho fundamental, cual es el de defensa.

31 SSTC 62/1983, 113/1984 y 147/1985.

32 De nacionalidad argelina: STC 71/1988.

33 SSTC 59/1982, 188/1991 y 181/1994. 
Ciertamente, el deber de los españoles de conocer el castellano hace suponer que ese conocimiento existe en la realidad, pero tal presunción puede quedar desvirtuada cuando el detenido o preso alega verosímilmente su ignorancia o conocimiento insuficiente o esta circunstancia se pone de manifiesto en el transcurso de las actuaciones policiales ${ }^{34}$. Curiosa doctrina ésta si se considera que, conforme con la legislación ordinaria vigente (Art. 231.3 de la LOPJ), no hay exigencia legal de intérprete para el caso de que las partes o los terceros actuantes en el proceso utilicen la lengua cooficial autonómica, actuaciones que surtirán de plena eficacia, y que sólo requerirán de traducción para el caso de pretender su eficacia fuera del territorio de la Comunidad autónoma. Sólo se contempla la posibilidad de no usar a lengua cooficial por el tribunal y los funcionarios de los juzgados si alguna de las partes alega indefensión, pero no así si lo hace una parte o un tercero: en ese caso sólo cabe traducción a instancia de parte que alegue indefensión, aunque no este acreditado que quien usa la lengua cooficial desconoce el castellano.

\section{TUTELA JUDICIAL EFECTIVA Y ASISTENCIA LETRADA EN LOS PROCEDIMIENTOS DE LA LEY DE EXTRANJERÍA.}

\section{A) Asistencia letrada Y LEGITIMACIÓN DE ENTIDADES Y ASOCIACIONES}

Una de las manifestaciones del derecho a la tutela judicial efectiva es el derecho a la asistencia y defensa de abogado en el proceso. Se trata de un derecho que carece de carácter absoluto, puesto que es compatible con el derecho de defensa que, en determinados casos previstos por la ley, la actuación de abogado y procurador sean facultativas, pudiendo asumir el propio litigante su defensa (en asuntos de hasta $900 €$ en el proceso civil; en juicios de faltas en el proceso penal).

La ley de extranjería contiene normas específicas sobre la asistencia letrada y defensa del procurador. El art. 22 de la Ley Orgánica 4/2000, en su redacción vigente, se refiere a esta asistencia con relación, de nuevo, al derecho a la asistencia jurídica gratuita, a la que anteriormente nos hemos referido. En puridad, el mayor interés del reconocimiento de este derecho estriba en la gratuidad de los servicios jurídicos de abogado y procurador, cuya actuación suele engrosar las partidas económicas más cuantiosas en el proceso. El reconocimiento del derecho implica, en caso de acreditarse insuficiencia de recursos para litigar, conforme con la Ley 1/1996, la posibilidad de encomendar la defensa y, en su caso, la representación técnica, a un abogado o procurador de oficio. En complemento del art. 22 citado, la Ley de Asistencia Jurídica

34 Vid la STC 74/1987, sentencia interpretativa resolutoria de un recurso de inconstitucionalidad del Gobierno vasco, por omisión, contra la legislación orgánica y procesal, que entiende conforme con la Constitución el derecho a intérprete del detenido, si se extiende a los españoles que aleguen desconocer el español: Art. 520.2, e, de la LECRIM. 
gratuita extiende la actuación del abogado de oficio al procedimiento administrativo previo al contencioso-administrativo (art. $2 \mathrm{f}$, según la redacción dada por la Ley 16/2005). También se extiende a la consulta previa del letrado antes de incoar el procedimiento, y a los análisis sobre la sostenibilidad del procedimiento (art. 6.1).

La vigente redacción del art. 22.1 de la Ley Orgánica 4/2000 tiene una novedad significativa con respecto a su tenor original, contenido en el art. 20 de la ley. En este último, se reconocía el derecho de todos los extranjeros al abogado de oficio en los procedimientos administrativos o judiciales de la ley de extranjería. El reconocimiento a la asistencia letrada de oficio no implicaba, empero, el reconocimiento del derecho a litigar gratuitamente, lo que significaba que los abogados tenían derecho a percibir sus honorarios profesionales, aun siendo designados de oficio, como si fueran abogados de libre designación. Por su parte, la norma no garantizaba con claridad la designación de un abogado de oficio, en caso de no darse los presupuestos materiales para el reconocimiento de la justicia gratuita. La redacción dada por la LO 2/2009 al precepto se refiere expresamente a la necesidad de la asistencia letrada en los procedimientos administrativos, pero no así en el contencioso-administrativo, con lo que, salvo declaración del derecho de asistencia jurídica gratuita, la ley veda la asistencia letrada del extranjero que no designe un abogado (lo que ocurrirá en no pocos casos), sin posibilidad de que se haga cargo de la defensa, en fase jurisdiccional, un abogado de oficio. Ello evita abusos de letrados que asumen la defensa sin la debida autorización del extranjero, pero del mismo modo puede privar de la defensa a muchos litigantes que no se encuentran en condiciones de elegir un letrado, más allá del asignado de oficio en vía administrativa.

La LO 2/2009 avala, por otra parte, el procedimiento de reconocimiento del derecho de asistencia jurídica gratuita que regula la Ley 1/1996 (con necesidad de solicitud por parte del interesado del reconocimiento del derecho y, hasta que éste se haya producido, designación provisional de abogado de oficio), con regulación de la posibilidad de solicitud por vía consular para extranjeros que se encuentren fuera de España (art. 22 de la LO 4/2000). El órgano administrativo debe designar una lista de dos nombres, pudiendo el primero declinar hacerse cargo de la defensa, en caso de considerar insostenible la pretensión, un procedimiento que se nos antoja complejo para asumir por extranjeros, normalmente en situación de irregularidad, y que para ser salvada puede ser capital la actuación de los servicios sociales de atención a los extranjeros.

Existe otra posibilidad para afrontar la defensa jurídica de los extranjeros: nos referimos a la prevista en el art. 20.3 y 4 de la Ley Orgánica 4/2000 (no afectados por la LO 2/2009) consistente en que la defensa de los derechos de los extranjeros, en vía administrativa o judicial, sea encarnada por las organizaciones constituidas legalmente en España para la defensa de los inmigrantes, expresamente designadas por éstos, o las entidades que resulten afectadas en los términos previstos por el art. 19.1.b) de la Ley regula- 
dora de dicha jurisdicción. Se trata, en este segundo caso, de los grupos de afectados, uniones sin personalidad o patrimonios independientes o autónomos, entidades todas ellas aptas para ser titulares de derechos y obligaciones al margen de su integración en las estructuras formales de las personas jurídicas, también tendrán capacidad procesal ante el orden jurisdiccional contencioso-administrativo cuando la Ley así lo declare expresamente (art. 18 LJCA) y las corporaciones, asociaciones, sindicatos y grupos y entidades a que se refiere el artículo 18, que resulten afectados o estén legalmente habilitados para la defensa de los derechos e intereses legítimos colectivos.

La articulación legal de esta defensa es a través del reconocimiento de legitimación extraordinaria a las entidades anteriores, en coherencia con lo que la propia Ley de Enjuiciamiento Civil de 2000 dispone, no la atribución de la representación legal. El matiz es importante, pues en estos casos quien es la parte procesal es la asociación o entidad de que se trate, y no el extranjero, por lo cual no es automáticamente aplicable la regla de asistencia jurídica gratuita del art. 22 de la Ley Orgánica 4/2000, referida sólo a la justicia gratuita de personas físicas, pero no de personas jurídicas. Salvo que, por aplicación supletoria de la Ley de asistencia jurídica gratuita se considere que se trata de asociaciones de utilidad pública (del art. 32 de la Ley Orgánica $1 / 2002$, reguladora del derecho de asociación), que acredite insuficiencia de recursos para litigar. Eso se produce según el art. 3.6, en relación con el art. 2.c de la Ley 1/1996, cuando su base imponible en el Impuesto de Sociedades fuese inferior a la cantidad equivalente al triple del salario mínimo interprofesional en cómputo anual. Y dependiendo de cómo se interprete el requisito del art. 3.4, según el cual el derecho de asistencia jurídica gratuita sólo se reconoce a quienes litiguen por derechos propios, algo que podría entenderse que no se produce en el caso de estas asociaciones, cuando encarnen la defensa de ciudadanos extranjeros.

\section{B) El PROBLEMA DE LA DEFENSA LETRADA SIN VOLUNTAD EXPRESA DE LITIGAR POR PARTE DEL EXTRANJERO}

En los últimos años se ha manifestado un problema que se genera en el caso de la asistencia legal de los abogados de oficio, y que ha provocado una de las reformas promovidas por el Gobierno en el proyecto de reforma de la Ley Orgánica 4/2000, que se encuentra actualmente en tramitación. Nos referimos al hecho que se produce cuando el abogado designado de oficio para asistir al extranjero en caso de denegación de su entrada en frontera, y una vez consumada la expulsión o la devolución del extranjero a su lugar de origen, decide incoar por su cuenta el recurso administrativo y con posterioridad continuar con el proceso contencioso-administrativo sin contar con el debido apoderamiento por parte del extranjero afectado y sin constancia expresa de la voluntad de éste de impugnar la decisión administrativa. 
El problema nace por un ejercicio del derecho de defensa por parte del abogado que no goza del debido aval del defendido, en este caso el extranjero, lo que origina gran litigiosidad en el orden contencioso-administrativo. Como se acaba de exponer, la situación normalmente aboca a la no admisión a trámite de la demanda en el proceso, pues entiende la jurisprudencia que la designación de letrado para asistencia jurídica en frontera no habilita al ejercicio de su defensa en vía administrativa y jurisdiccional, al amparo de lo dispuesto en el artículo 23 de la Ley Reguladora de la Jurisdicción Contencioso Administrativa (Ley 29/1998, de 13 de julio) ${ }^{35}$.

Como se acaba de exponer, además, la designación de abogado de oficio, salvo casos excepcionales (como ocurre precisamente con la asistencia letrada al detenido), exige la manifestación por parte del justiciable de la voluntad de litigar, que es lo que le mueve a solicitar la asistencia justicia gratuita (y, con ello, la designación de abogado del turno de oficio). La situación conduce a una suerte de justicia virtual, que se sigue incluso en dos instancias jurisdiccionales, sin que ni siquiera conste el paradero ni el domicilio del recurrente (aunque algunos expertos entienden que basta, para legitimar la actuación del abogado, con la actuación del extranjero no se deduzca su voluntad de no impugnar una eventual decisión administrativa de devolución o expulsión ${ }^{36}$ : con la particularidad de que podría entenderse que se lesiona la tutela judicial efectiva del extranjero cuando se ejerce el derecho de defensa en su nombre, pero sin su consentimiento, incluso, en contra de su voluntad.

Para poner remedio a este asunto, la reforma actualmente en tramitación de la Ley orgánica 4/2000, contemplaba la introducción de un nuevo artículo 22 bis, bajo la denominación de "Postulación procesal", exigiendo que el reconocimiento de asistencia jurídica gratuita requiriese una nueva solicitud en caso de voluntad de impugnación de la resolución administrativa en vía jurisdicciona ${ }^{37}$. El informe del CGPJ al Anteproyecto de Ley observaba proble-

35 Que exige que al interponer el recurso contencioso-administrativo la representación del recurrente esté debidamente acreditada por cualquiera de los medios previstos en el art. 24 de la Ley de Enjuiciamiento Civil. Postura avalada por la jurisprudencia del Tribunal Constitucional: "Este Tribunal ha afirmado que es difícilmente rebatible la tesis de que para actuar en nombre de otro en un proceso resulta imprescindible el consentimiento expreso o inequívoco del representado, consentimiento habitualmente conferido a través del instrumento del poder notarial" (ATC 276/2001, de 29 de octubre) o del poder apud acta (STC 205/2001, de 15 de octubre)" (ATC 296/2006, de 6 de septiembre, F.J. $6^{\circ}$ ).

36 Sobre este problema, vid el informe de CÓRDOBA CASTROVERDE, D., "La asistencia jurídica de los extranjeros devueltos en frontera y la continuación de la vía administrativa judicial. Foro abierto", Revista de Jurisprudencia El Derecho, no 1, pág. 6.

37 «1. En los procesos contencioso-administrativos, el reconocimiento del derecho a la asistencia jurídica gratuita requerirá una nueva solicitud y la constancia expresa de la voluntad del extranjero de interponer el recurso o ejercitar la acción correspondiente. La manifestación de la voluntad de recurrir la resolución administrativa deberá realizarse por cualquiera de los medios previstos en el artículo 24 de la Ley 1/2000, de 7 de enero, de Enjuiciamiento Civil.

2. Cuando el extranjero se encuentre fuera de España, la solicitud del derecho a la asistencia jurídica gratuita y la manifestación de la voluntad de recurrir la resolución administrativa podrán realizarse ante la misión diplomática u oficina consular correspondiente." 
mas de constitucionalidad de esta norma, por considerar que se daba un tratamiento diferente a los extranjeros y a los españoles, más gravoso para aquellos, pues el Art. 7 de la Ley de asistencia jurídica gratuita dispone que el reconocimiento de la asistencia jurídica gratuita se extendía a todas sus instancias y recursos ${ }^{38}$.

A nuestro entender, sin embargo, no es así, toda vez que no se puede entender que el proceso contencioso-administrativo es una instancia más de un mismo proceso iniciado con el vía administrativa previa: la fase administrativa no forma parte del proceso judicial por lo cual son perfectamente compatibles, a nuestro entender, las dos normas anteriores, sin que se aprecie el senalado tratamiento diferenciado. Con todo, finalmente la norma no se ha introducido en el articulado de la LO 4/2000.

\section{LA TUTELA JUDICIAL DEL EXTRANJERO COMO GARANTÍA DE RESPETO CONTRA LA ACTUACIÓN DE LOS PODERES PÚBLICOS Y MEDIDAS RESTRICTIVAS DE DERECHOS EN PROCEDIMIENTOS ADMINISTRATIVOS DERIVADOS DE LA LEGISLACIÓN DE EXTRANJERÍA.}

\section{A) Control jurisdiccional de las medidas Restrictivas De DERECHOS FUNDAMENTALES}

El derecho a la tutela judicial efectiva no sólo se extiende, de acuerdo con su contenido esencial, al derecho a obtener una resolución fundada en Derecho, que ponga fin al procedimiento. Por la posición que ocupa el poder judicial con respecto a los demás poderes del Estado, la actuación de la administración pública está sometida al control jurisdiccional (Art. 106.1 de la CE) y, en el caso de restricción de derechos fundamentales la intervención de la autoridad judicial se hace patente (Arts. 17 y 18 de la CE, en relación con la inviolabilidad del domicilio y de las comunicaciones, así como con el plazo para poner al detenido a disposición judicial).

Ello se produce igualmente en los procedimientos administrativos de extranjería, en que se puede someter al extranjero a medidas de restricción de la libertad (internamiento previo a la orden de retorno o de devolución: arts. 60 y 61 de la Ley Orgánica 4/2000). La adopción de estas medidas esta sujeta a la oportuna intervención de la autoridad jurisdiccional, que se

38 Literalmente: "1. La asistencia jurídica gratuita en el transcurso de una misma instancia se extiende a todos sus trámites e incidencias, incluida la ejecución, pero no podrá aplicarse a un proceso distinto.

2. El derecho a la asistencia jurídica gratuita se mantendrá para la interposición y sucesivos trámites de los recursos contra las resoluciones que pongan fin al proceso en la correspondiente instancia, aplicándose en este caso lo dispuesto en el artículo 32 de la presente Ley". 
debe producir dentro de las 72 horas posteriores a la detención cautelar del extranjero ${ }^{39}$.

La medida de internamiento se puede acordar en el seno de un expediente administrativo de expulsión, en el caso de ejecución inmediata de la orden de expulsión si ha habido solicitud de asilo de solicitante en puesto fronterizo (declarado constitucional el Art. 5.7 de la Ley 5/1984, reguladora del derecho de asilo y del estatuto del refugiado en este punto, al considerarse que no afecta al derecho a la libertad el ingreso en dependencias adecuadas durante la tramitación de la solicitud — se trata de un plazo máximo de 4 días hasta al decisión de admisión a trámite y de dos días más si se solicita el reexamen de la inadmisión y mantenido en la nueva Ley 12/2009), y hasta que esta no se inadmitida, o en caso de retorno de extranjero al punto de origen, cuando no hay medios para ejecutarlo automáticamente.

La orden de internamiento compete al Juez de instrucción (Art. 60 y concordantes de la Ley), es decir, al Juez penal, a quien corresponde el control sobre el respeto a los derechos del interno están sometidos al control de la jurisdicción contencioso-administrativa: lo que no puede hacer es controlar la legalidad del expediente administrativo, atribuido, por la Ley de la Jurisdicción Contencioso Administrativa (Art. 8.4), tras su reforma por la Ley Orgánica 19/2003, a los Juzgados de lo contencioso-administrativo, lo que veda el acceso al Tribunal Supremo de muchos de los asuntos, salvo por la vía de la vulneración de derechos fundamentales del Art. 5.4 constitucional. Es posible también la intervención del Juez de instrucción, si el internamiento es ordenado en el seno de un proceso penal, o en caso de que el detenido o interno invoque el habeas corpus (Ley Orgánica 6/1984), lo que implica su inmediata puesta a disposición judicial en caso de detención o internamiento ilegal o de haberse pasado el plazo legal del internamiento. Cabe, pues, la intervención de dos órganos jurisdiccionales pertenecientes a órdenes diferen-

39 Artículo 89 del Código Penal:

1. Las penas privativas de libertad inferiores a seis años impuestas a un extranjero no residente legalmente en España serán sustituidas en la sentencia por su expulsión del territorio español, salvo que el juez o tribunal, previa audiencia del Ministerio Fiscal, excepcionalmente y de forma motivada, aprecie que la naturaleza del delito justifica el cumplimiento de la condena en un centro penitenciario en España.

Igualmente, los jueces o tribunales, a instancia del Ministerio Fiscal, acordarán en sentencia la expulsión del territorio nacional del extranjero no residente legalmente en España condenado a pena de prisión igual o superior a seis años, en el caso de que se acceda al tercer grado penitenciario o una vez que se entiendan cumplidas las tres cuartas partes de la condena, salvo que, excepcionalmente y de forma motivada, aprecien que la naturaleza del delito justifica el cumplimiento de la condena en un centro penitenciario en España.

La expulsión se llevará a efecto sin que sea de aplicación lo dispuesto en los arts. 80, 87 y 88 del Código Penal.

La expulsión así acordada llevará consigo el archivo de cualquier procedimiento administrativo que tuviera por objeto la autorización para residir o trabajar en España.

En el supuesto de que, acordada la sustitución de la pena privativa de libertad por la expulsión, ésta no pudiera llevarse a efecto, se procederá al cumplimiento de la pena privativa de libertad originariamente impuesta o del período de condena pendiente. 
tes, para someter a tutela el derecho a la libertad del extranjero afectado por la medida. Si el extranjero sometido al expediente de expulsión estuviera inculpado en proceso penal por hecho el que la ley prevea pena inferior a seis años de privación de libertad o pena de otra naturaleza, la decisión de expulsión corresponde al juez instructor, en el plazo de tres días previa Audiencia del Ministerio Fiscal.

La jurisprudencia constitucional avala el uso del habeas corpus en materia de procedimientos administrativos de la ley de extranjería (SSTC 14/1994, 21/1996, 144/1990; entre otras $)^{40}$.

\section{B) El DEBER DE MOTIVACión DE LAS RESOluCiONES ADMINISTRATIVAS \\ EN MATERIA DE EXTRANJERÍA Y CONTROL DE LA ARBITRARIEDAD \\ DE LA AUTORIDAD PÚBLICA. (STC 236/2007)}

La tutela judicial efectiva exige, asimismo, el deber de motivación de las resoluciones judiciales. Ese mismo deber se justifica como medida de control contra la arbitrariedad del juez y garantía de sumisión a la ley en sus decisiones.

Así se reconoce genéricamente también en materia administrativa, adonde se han trasladado, para la tramitación de expedientes administrativos, las garantías derivadas de la tutela judicial ${ }^{41}$. En el caso concreto de los derechos de los extranjeros, el Art. 20.2 de la Ley Orgánica 4/2000, establece como garantía de los procedimientos administrativos de la ley, el respeto a lo relativo a publicidad de las normas, contradicción, audiencia del interesado y motivación de las resoluciones. El problema surge porque el inciso final del Art. 20.2 establece una excepción (salvo lo dispuesto en el art. 27 de esta Ley) ${ }^{42}$. La norma fue recurrida en inconstitucionalidad ante el Tribunal Constitucional, en el procedimiento resuelto por la STC 236/2007, por entenderse que la redacción permitía entender supuesto en los que al denegación del visado no estuviera motivada. El Alto Tribunal, consideró, sin embargo, que, siendo cierto el hecho aludido, no hay obligación constitucional de motivar la denegación del visado cuando su otorgamiento es fruto de una facultad discrecional del Estado, y no la consecuencia del ejercicio de un derecho. Se afirma ade-

40 Sobre la actuación del juez penal en procedimientos de extranjería, vid. TOMÉ GARCÍA, J. A., Intervención del juez penal en la expulsión de extranjero : internamiento preventivo: autorización judicial para la expulsión administrativa del inculpado o procesado: expulsión judicial sustitutiva del condenado, Madrid, Colex, 2006.

41 Art. 54 de la Ley 30/1992, de Régimen Jurídico de las Administraciones Públicas y de Procedimiento Administrativo Común.

42 "La denegación de visado deberá ser motivada cuando se trate de visados de residencia para reagrupación familiar o para el trabajo por cuenta ajena. Si la denegación se debe a que el solicitante del visado está incluido en la lista de personas no admisibles prevista en el Convenio de aplicación del Acuerdo de Schengen de 14 de junio de 1990, se le comunicará así de conformidad con las normas establecidas por dicho Convenion. 
más, que los riesgos de arbitrariedad quedan salvados por el ulterior control de la jurisdicción contencioso-administrativa. No hay pues restricción de un derecho fundamental en la denegación del visado, pues no hay derecho reglado a la concesión del visado.

\section{C) Vulneración del DERECHO a la TuTELA JUdiCial POR CAUSA DEL CARÁCTER SUMARIO DEL PROCEDIMIENTO PREFERENTE}

Una última cuestión relacionada con la tutela judicial de los extranjeros en los procedimientos de la Ley Orgánica 4/2000 atañe a la sumariedad (en el sentido de rapidez) del procedimiento administrativo preferente de expulsión en determinado supuestos, previsto en el Art. 63 de la Ley (son los casos de las letras a) y b) del apartado 1 del art. 54, así como las a), d) y f) del art. 53). De acuerdo con la norma (Art. 63.2 a 4), cuando de las investigaciones se deduzca la oportunidad de decidir la expulsión, se dará traslado de la propuesta motivada por escrito al interesado, para que alegue lo que considere adecuado, en el plazo de cuarenta y ocho boras. Con derecho a la asistencia letrada que se proporcionará de oficio, en su caso, y a ser asistido por intérprete, y de forma gratuita en el caso de que careciese de medios económicos.

Para el Tribunal Constitucional (STC 236/2007, F. J. 16 ${ }^{\circ}$ ) la pretendida indefensión que generaría el precepto no es tal, pues la brevedad de los plazos no implica per se la vulneración del derecho a la tutela judicial efectiva si con ello se tiende a hacer efectivo el principio de celeridad en el proceso, ya que es constitucionalmente inobjetable que el legislador prevea tal reducción en los plazos cuando dicha decisión responde a una finalidad razonable y necesaria, acorde con los principios que han de regir el procedimiento correspondiente.

TITLE: The clause "Due process of Law" and the foreigners seen from the perspective of the Organic Act 2/2009 and the Constituctional Court Decisions.

ABSTRACT: The work, starting from the analysis of the right of foreigners to a fair trial in Article 24.1 of the Spanish Constitution of 1978, studies the evolution of the doctrine of the Spanish Constitutional Court, remarking some of the most relevant cases and its reflection in the Spanish legislation (Cautio judicatum solvi, arrest, legal aid or constraints for non Spanish people to private prosecution in criminal proceedings, among others). It also discusses some aspects of the role of jurisdiction as a means of controlling public authorities' decisions that restrict fundamental rights related to foreigners, and their reflection in the recent reform of the Aliens Act of 2000, under the Organic Law 2 / 2009.

RESUMEN: El trabajo, desde el reconocimiento de la titularidad por parte de los extranjeros del derecho a la tutelea judicial del Art. 24.1 de la Constitución de 1978, estudia la evolución de la doctrina del Tribunal Constitucional, con análisis de algunos de los casos más relevantes y su reflejo en la legislación española. Se aborda, de este modo, el tratamiento de la cautio judicatum solvi, el embargo preventivo, la asistencia jurídica gratuita o las limitaciones a los no españoles para 
ejercer la acción penal. También se analizan algunos aspectos sobre el papel de la jurisdicción como instrumento de control de los poderes públicos a la hora de adoptar medidas restrictivas de derechos fundamentales en materia de extranjeria, y su reflejo en la reciente reforma de la Ley de Extranjería del año 2000, en virtud de la Ley Orgánica 2/2009.

KEY WORDS: Fair trial. Foreigners. Legal aid. Constitutional Court.

Palabras Clave: Tutela judicial. Extranjeros. Asistencia jurídica gratuita. Tribunal Constitucional. 